\title{
0-357 低悪性度耳下腺癌の術前穿刺吸引細胞診の成績
}

○横島一彦、中溝宗永、稲井俊太、酒主敦子、坂井 梓、加藤大星、大久保公裕

日本医科大学付属病院 耳鼻咽喉科・頭頸部外科

[はじめに］耳下腺癌に対する適切な術式の選択は難しい。特に、低覀性度癌では画像診断に特異的な所見がないため、 細胞診に頼らざるを得ないが、その正診率は高いとは言えない。そこで、低悪性度耳下腺癌自験例で細胞診の成績を検討 し、現状の解決に向けての工夫を考察した。［対象］1998年から2014年までの17年間に手術を施行した低悪性度耳下腺癌 21 例を対象にした。腺房細胞癌 12 例、粘表皮癌 6 例、基底細胞癌 2 例、多形腺腫由来癌 1 例であった。平均年齢57.9歳、男性

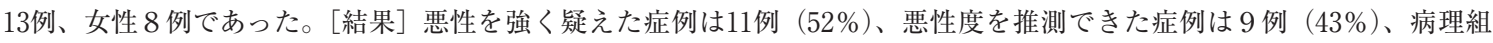

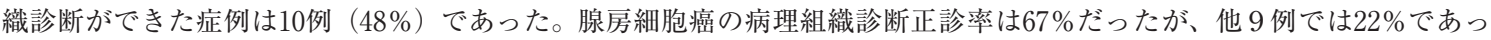
た。[考察］細胞異型が軽度で、壊死を伴うことが少ないため、悪性を示唆することもできず、正診率が低いと考えられた。 その中で、腺房細胞癌は細胞学的な特徵から診断可能な症例が多かったものの、それ以外は多様な細胞形態のため悪性診断 も不可能なことが多いと考えた。

\section{0-358＼cjkstart慢性めまい平衡障害に対する前庭平衡リハビリテーションの効果}

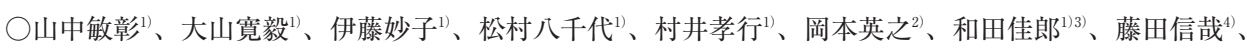
北原 糺1)

奈良県立医科大学附属病院 耳鼻咽喉・頭頸部外科 /めまいセンター ${ }^{12}$ 市立奈良病院 耳鼻咽㘈科 ${ }^{2} 、$ 和田耳鼻咽喉科 ${ }^{3)}$ 、日生病院 耳鼻咽喉科 ${ }^{4)}$

【目的】慢性化した末梢前庭障害の治療には平衡リハビリテーションが適用される。今回、当科で行っているトレーニン グ法を紹介するとともに、その効果について検討した。

【方法】一側性前庭障害を有し、薬物治療を行っても効果のなかった慢性めまい症例42例を対象とした。平衡リハビリテ ーションを 1 年間行って効果判定を行った。めまいの自覚症状の評価にはVisual Analogue Scale、QOLの評価には Dizziness Handicap Inventory を用い、他覚的評価として重心動摇検査、歩行検査を行った。

【成績】トレーニングの全期間を通してすべての項目の改善が認められた。1 カ月後より効果が発現し、 3 カ月後に全症 例の約 $60 \%$ 、6 月月後には約70\%に改善が認められたが、6 月から 1 年後の間には効果に変化はみられなかった。

【結論】前庭平衡リハビリテーションは、慢性化しためまい平衡障害に対する治療として、めまい症状や平衡機能、QOL の改善に有用であることが示唆され、少なくとも 6 カ月間のトレーニング期間が勧められる。

\section{0-359 リアルタイム三次元解析可能な Video-oculography 製品と次世代赤外線フレンツェルの開発}

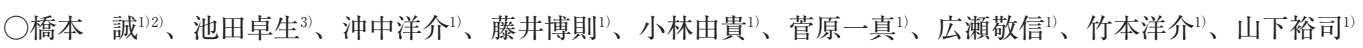
山口大学大学院医学系研究科 耳鼻咽喉科学 ${ }^{11}$ 、山口大学医学部附属病院 高次統合感覚器医療センター ${ }^{21}$ 、 鼓ヶ浦こども医療福祉センター 耳鼻咽喉科 ${ }^{3)}$

これまでにわれわれは、フリーウェアの画像解析ソフト ImageJ を用いた video-oculograhy（HI-VOG）を開発し、報告 してきた。HI-VOG は、オフライン解析であること、手動による瞳孔認識設定が必要であること、回旋成分の解析に時間が 必要であること、など問題点や限界があった。そこで今回、改良したVOG 製品（yVOG）を開発した。

普及型赤外線 $\mathrm{CCD} / \mathrm{CMOS}$ カメラで利用可能とした。タッチパネル操作式 PC を用い、検査種目別に録画・ファイリン グ、瞳孔認識・解析の自動化、リアルタイム眼振図表示を可能にした。画像処理方法については、キャリブレーション後画 像を二值化し、水平・垂直成分は曈孔中心座標、回旋成分は虹彩紋理の抽出とパターンマッチングで求めた。履歴検索、再 生、詳細解析、報告書作成機能を加えた。さらに高速度カメラを搭載した軽量赤外線フレンツェルの開発をすすめている。

\section{0-360＼cjkstart高齢めまい患者の転倒リスクの検討一DHI と重心動摇のトレンド除去変動解析結果の相関から一}

○水田啓介、青木光広、林 寿光、西堀丈純、久世文也、伊藤八次 岐阜大学 医学部 耳鼻咽喉科

重心動摇時系列デー夕に対するフラクタル解析であるトレンド除去変動解析（Detrended fluctuation analysis, DFA）によ り、姿勢制御の複雑性、適応性を評価でき、高齢者では DFA のスケーリング指数 ( $\alpha$ 指数 $)$ が易転倒性の指標になるとい う報告がある。Dizziness handicap inventory(DHI) はめまいによる日常生活の障害度を評価する質問票であるが、高い DHI をもつ高齢平衡障害者では転倒回数が多いという報告がある。今回われわれは、高齢者の重心動摇 DFA $\alpha$ 指数が転倒 の指標になるかを検討することを目的に、高齢めまい患者の重心動摇の標準解析結果および DFA $\alpha$ 指数と DHI（合計点、 $\mathrm{P}$ 因子点、 E 因子点、F因子点）との相関を、非高齢一側迷路障害と比較検討した。非高齢一側迷路障害では DFA $\alpha$ 指数 と DHI は有意な相関を示さなかったが、高齢めまい患者では DFA $\alpha$ 指数と DHI（合計点、P 因子点）は有意な負の相関を 示した。この結果から、高齢者の DFA $\alpha$ 指数は転倒にかかわる日常生活動作中のふらつきを反映する可能性があると思わ れた。 


\section{0-361＼cjkstart地震後のめまいの普遍性について}

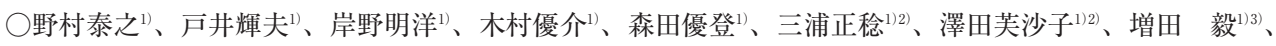
鴫原俊太郎 ${ }^{11}$ 、大島猛史 ${ }^{11}$

日本大学 医学部 耳鼻咽喉・頭頸部外科学分野、川市、立医療センター ${ }^{2)}$ 、増田耳鼻咽喉科医員 ${ }^{3)}$

【背景、目的】大地震の後に、実際には地面が摇れていないにもかかわらずあたかも摇れているかのように自覚する「地 震後めまい症候群」が生じることが判ってきた。われわれは2011年の東日本大震災の際に約3, 000名の疫学調査を行い、そ の症候の疫学的特徵や病態メカニズム、そして予防法などを検討してきた。また 2016 年の熊本地震でも約 2,000 名に同様の 調査を実施し、その症候が東日本大震災の時と似ていることを実証した。このことから「地震後めまい症候群」は単発的な 事象ではなく大規模な地震において普遍的に生じることが示唆された。本報告ではさらに2016年に生じた鳥取地震を含めて 症候の特徴をまとめてみることを目的とした。

【対象、方法】東日本大震災、熊本地震、鳥取地震で行った同様内容の質問紙法調查の結果から相似点、差異点を探る。

【結果、考察】幾つかの相違点は認めるものの疫学的特徵は類似していた。ただし地震の強度や調査地の社会不安の程度 が症候の出現に影響する可能性も考えられた。

\section{0-362＼cjkstart神経耳科学的所見に乏しい女性の慢性浮動性めまい症例について検討}

○伏木宏彰、角田玲子

目白大学耳科学研究所クリニック 耳鼻咽喉科

【目的および対象】神経耳科学的検査で有意な異常は認められないものの、症状が長引く女性の浮動性めまい症例にしば しば遭遇する。本症の臨床的特徵を明らかにすることを目的とし、頭痛、不安や抑うつ等の併存症状拉よび血液生化学的検 查所見について検討した。対象は、平成 26 年 1 月から平成 28 年 9 月までの間に当科を受診し、1）神経耳科学的検査にて平 衡機能に異常がなく 3 カ月以上長引く浮動性めまい症例、および 2) 初期に認められた平衡機能障害が改善したにもかかわ らずその後もめまいやふらつきを自覚している症例とした。

【結果】慢性浮動性めまい症例では、頭痛、不安やうつ傾向を有する割合が高かった。難治例では、めまい日誌の活用、 東洋医学的治療やカウンセリングの併用が有効であった。女性ホルモンは多くが正常範囲内であった。

【結論】女性の長引く浮動性めまい症例では、頭痛や不安、抑うつといった副症状に留意する必要がある。更年期の浮動 性めまい例では、婦人科との連携も一考する必要があると思われた。

\section{0-363 めまいを主訴に当院救急外来を受診した症例の検討}

○海邊昭子、大村和弘、蓮 琢也、田中康広

獨協医科大学越谷病院 耳鼻咽喉科

救急外来におけるめまい診療は、中枢障害によるめまいをいち早く鑑別することが最も重要なポイントである。しかしな がら、めまいはさまざまな病態を包括した非特異的な訴えに加え、担当する診療科医師によって診察方法の違いがあるた め、診断へのアプローチが統一されて扔らず、多科での診療連携のもと患者対応を行っている。

2015年11月から 2016 年10月の 1 年間にめまいを主訴に当院救急外来を受診した183症例（男性68例、女性115例）を対象と し、年齢、性別、受診方法、既往歴（糖尿病、高血圧症、心臟や頭蓋内の血管病変）、めまい症の既往の有無、めまいの性 状、持続時間、随伴症状（頭痛、耳鳴、小脳症状、高血圧、嘔吐）、眼振の有無、入院の有無の10項目と診断との関係につ いて後ろ向きに検討した。

受診方法の内訳は救急搬送が128例、独歩は55例であり、うち54例が入院となった。この54例の患者に対し、上記 10 項目 について症状の重症度や中枢性めまいと相関のある項目の有無を評価し、文献的考察を含めて報告する。

\section{0-364 HPV 関連中咽頭癌症例における TNM 分類改訂に伴う病期分類と生存率の検討}

○水町貴諭、本間明宏、坂下智博、加納里志、畠山博充、福田 諭 北海道大学 大学院 医学研究科 耳鼻咽喉科・頭頸部外科学分野

【はじめに】HPV 関連中咽頭癌は非関連癌と比べ予後が良好であり、UICC の TNM 分類第 7 版は予後を反映されなくな った。2017年に改訂される第 8 版では HPV 関連癌において、新しい分類基準が設けられた。今回われわれは当科症例にお いて新・旧病期分類と生存率の比較検討を行った。

【対象と方法】1998年から2014年に当科にて加療を行った HPV 関連中咽頭癌83例を対象に後方視的に検討を行った。 HPV 関連の評価は第 8 版にしたがって p16 免疫染色にて行った。

【結果】HPV 関連癌において第 7 版分類では大半が $V$ 期であったが、第 8 版分類では大半が $I$ 期と分類された。第 7 版分 類による 3 年粗生存率は I-III 期と IV 期の間に統計学的有意差を認めなかったが、第 8 版分類では I - II 期と III 期の間に有意 差を認めた。

【考察とまとめ】HPV 関連癌においては第 7 版分類では予後が反映されていないが、第 8 版では反映されることが当科症 例でも明らかとなった。第 8 版は分類基準が大幅に変わるのでその取扱いに注意が必要である。 